\title{
Research on Chinese High-School Students' English Learning Motivation from the Self System Perspective
}

\author{
Minzi Li \\ National Key Center of Linguistics and Applied Linguistics, \\ Guangdong University of Foreign Studies, \\ No. 2 Baiyun Street, Guangzhou, Guangdong, 510420, China
}

\begin{abstract}
L2 motivation has been proven to be an important factor for second language learning. The newly proposed framework of the L2 Motivational Self System by Dörnyei has offered researchers valuable insights into L2 motivation. However, few studies have been conducted on the L2 motivation of the English learners from a self perspective in the Chinese context. In consideration of the research gap and the distinctiveness of the Chinese high-school learners, this research aimed to explore L2 motivation among Chinese high-school students from the Self System perspective. A mixed methods approach of the questionnaire with follow-up semi-structured interview was utilized in the study. 128 students (randomly selected) from 4 high-schools in Wuhan in central China filled in the questionnaire survey, and six of them joined the interview. The results of the study showed that: 1) the key component of the L2 Motivational Self System, the Ideal L2 Self cannot be the reinterpretation of integrativeness in Chinese educational contexts; 2) among three dimensions of the Self system, the language learning experience had the highest correlation with learners' motivation, followed by the Ideal L2 Self, with the Ought-to L2 Self produced the weakest correlation. Based on findings, some practical implications for English teaching are revealed.
\end{abstract}

Keywords: L2 Motivational Self System, English language learning, Chinese high-school students, integrativeness, the Ideal L2 Self, the Ought-to L2 Self, language learning experience

DOI: $10.7176 / \mathrm{JEP} / 10-26-07$

Publication date:September $30^{\text {th }} 2019$

\section{Introduction}

1.1 The Importance of L2 Motivation in Second Language Learning

Motivation refers to an internal process that prompts the individual's desire to participate in an activity and drives the behavior to maintain the action (Reeve, 2014). Though second language learning (SLL) is affected by various factors, motivation is deemed as one of the most important factors (Winke, 2007) and its importance have been examined by many experts in the area as most studies have reported positive correlations between motivation and learners' achievements in SLL (Gardner, 2007; Masgoret \& Gardener, 2003). Due to the complexity and dynamic nature of motivation, researchers were hard to see the whole picture of its construct and yet reached no consensus toward its definition (Kleinginna \& Kleinginna, 1981). However, this aroused considerable attention within the field of second language learning and stimulated further studies in the past 50 years. According to Liu (2007), motivation has been a major topic in SLL since the 1950s and there has been a growing number of researches on L2 over the last several decades. Zhou and Rao (2007) further asserted it "the most-worthy researched factor of second language learning".

Dörnyei proposed a new framework, namely, "the L2 Motivational Self System" based on the previous theory of "self" (Dörnyei, 2007). This new approach has broadened the scope of L2 motivation studies and provided us with more practical implications as it "opens up a novel avenue for motivating language learners" (Dörnyei, 2007). Liu (2007) further claimed that this new construct may offer teachers effective pedagogical guidance to motivate students.

\subsection{The Importance of L2 Motivation among High-School Students in the Chinese Context}

English, a widely spoken language, has become a global lingua franca (Crystal, 2012). The numbers of English learners have experienced a sharp increase in the context of the emerging global economy, especially notable in developing countries due to the expanding economy and high demand for English talents, such as China. Among the large population of English learners in China, their motivation to acquire English may vary and this may be due to the differences in teaching methods, varied quality of education, or the degree learners being exposure to the English learning environment (Wen \& Wang, 2004). Besides, Chinese high-school students are distinctive among all English learners. First, they have a strong desire to prepare for the high-stakes exam named Chinese National College Entrance Examination. The exam held once a year and pivotal to their future development (e.g., future education or career). Among all components of the exam, the score for English occupied the highest proportion (nearly a quarter of the total score), and thus can be viewed as the vital reason for high-school students to acquire English. Second, the distinctiveness of high-school learners can be ascribed to their young 
age. They are at a stage of change as their traits and interests are changing and can be affected by numerous factors. Hence, their motivation to learn English can be presumably complicated and of great uncertainty. Moreover, current literature seemed to have rare discussions about the L2 motivation of Chinese high-school learners from a perspective of the L2 Motivational Self System.

Considering the importance of motivation in SLL, the framework proposed by Dörnyei together with the distinctiveness of the high-school English learners in the Chinese Context, it is, therefore, worthy exploring Chinese high-school students English learning motivation from the Self System perspective.

\section{Literature Review}

\subsection{The Construct of Motivation}

There is no consensus definition of the construct motivation since its meaning varies in different disciplines, such as in the fields of education and linguistics. Kleinginna and Kleinginna (1981) even listed 102 categorized statements toward its construct. Gardner (2007) also claimed, "motivation is a very complex phenomenon with many facets" (p.10) and it cannot be defined in a few words. According to Gardner (1985), motivation associated with SLL is characterized by the willingness to learn the language, the degree of intended effort and enjoyment of engaging activities. As Ushioda (1996) defined, L2 motivation is deemed as dynamic arousal that directs and guides the internal process of acting out one's desires to learn a second language. With the development of theories on L2 motivation over the past 50 years, its dynamic nature has been widely investigated. Dörnyei(2009b) indicated that the dynamic characteristics of motivation could be interpreted as a form of power that changes in accordance with the temporal factors. In this sense, L2 motivation can be viewed as a dynamic impetus that varies with time or environment.

\subsection{Theoretical Framework of L2 Motivation}

Researches into L2 motivation has evolved through four distinct periods: social-psychological (1959-1990), cognitive-situated (during the 1990s), process-oriented (at the turn of the century) and socio-dynamic (current) period (Dörnyei \& Ushioda, 2013). Emphasis of this paper will only be centered upon the integrativeness in from a social-psychological period and the L2 Motivational Self System in the socio-dynamic period.

\subsubsection{Integrativeness}

One of the most influential theories in L2 motivation within the social-psychological period is the socioeducational model proposed by Gardner (1985). The model identifies two orientations of motivation, namely, instrumental and integrative motivation. The former aspect emphasizes the pragmatic gains from the L2 achievement, while integrative motivation refers to the desire to acquire the target language of the community and obtain positive feelings from SLL (Yashima, Zenuk-Nishide \& Shimizu, 2004). According to Dörnyei \& Ushioda (2011), it is comprised of three components, integrativeness, motivation and attitudes toward the learning environment. Among three, integrativeness has drawn substantial attention of researchers who seek to investigate its relationship with the other two variables (intensity and the learning process). It refers to the individual's willingness to communicate with members of other communities (Gardner, 2011) and it has been proved to be the most powerful variable affecting learners' intended effort (Dörnyei \& Clément, 2001).

2.2.2 The L2 Motivational Self System

During the socio-dynamic period, Dörnyei (2005) proposed a new perspective the L2 Motivational Self System under the background of: 1) the need of redefining integrativeness, 2) theoretical development of possible selves and 3) inspiration from the findings of a longitudinal study Dörnyei, Csizér, and Németh (2006) in Hungary.

(1) Reinterpretation of Integrativeness

Though integrativeness has been served as the core factor of L2 motivation over the past several decades, there has been a growing dissatisfaction with its construct (Dörnyei, 2009) as the inconsistent and invalid results in empirical studies were detected (Liu, 2007). Moreover, some researchers doubted that integrataiveness can only be an effective indicator when employed in specific cultures (Dörnyei \& Ushioda, 2011). Therefore, increasing doubts of integrativeness gave rise to a strong need for the reinterpretation of integrativeness.

(2) Theoretical Development of Possible Selves

Coupled with the need to reinterpret the notion of integrativeness, the theoretical development of possible selves contributed to the proposal of the Self system. The concept of possible selves was first introduced by Markus and Nurius (1986) which refers to individuals' visions of the future self and reflect one's progress one from past to present to future (Dörnyei \& Ushioda, 2009). Higgins, Klein, and Strauman (1985) further developed two orientations of the self-theory, namely, the ideal self and the ought-to self. The former concerns one's desire for what he ideally would like to have, while the latter specifies the beliefs from others of responsibilities one should have.

(3) A Longitudinal Motivational Study

A large-scale longitudinal motivational research study by Dörnyei, Csizér, and Németh (2006) also paved the way for the L2 Motivational Self System. In the study, importance of integrativeness to L2 motivation was 
proved. However, Dörnyei would like to incorporate it into a broader factor of L2 motivation, the Ideal L2 Self (Dörnyei \& Ushioda, 2011).

To sum up, all these factors contributed to the proposal of the L2 Motivational Self System.

The definition of the L2 Motivational Self System in the study was adapted from Dörnyei and Ushioda (2011), containing three key dimensions: 1) Ideal L2 self which refers to one's future imagination about his language achievement and thus minimizes the gap between the ideal and actual self; 2) Ought-to L2 self which indicates the thoughts from others about the obligations or responsibilities one should have; and 3) L2 Learning Experience which specifies language learning environments and experiences.

The three dimensions of the L2 Motivational Self System are compatible with previous L2 motivational theories that identify motivation as a tripartite notion. First, three components of the Self system (the Ideal L2 Self, the Ought-to L2 Self and language learning experience) are parallel to integrativeness, instrumentality and attitudes toward the learning situation respectively in Gardner's Socio-Educational Model (Gardner, 1988). Second, these components are compatible with three dimensions (integrative, extrinsic and intrinsic aspects) in the motivation construct put forward by Noel (2001). Similarly, key components from the Self system are also consistent to the actual learning process, external incentives, and integrative factors proposed by Ushioda (2001), and therefore offers theoretical validation for the Self system.

Along with the theoretical validation for the L2 Motivational Self System, empirical studies have been conducted to validate the theory and intended to examine the core component the Ideal L2 Self in different contexts. Kormos and Csizér (2008) investigated the L2 motivation across three group learners in terms of the Ideal L2 Self, the Ought-to L2 Self and International Posture. Further, in the study of Csizér and Kormos (2009), they incorporated new variables such as family influence and knowledge orientation for further investigation. To address issue relating to the country-specific, Taguchi, Magid, and Papi (2009) carried out study across three countries. In this research, the three core variables of the L2 Motivational Self system were empirically validated for the first time. Further, Ryan (2009) probed the Ideal L2 Self in the Japanese education settings. Interesting, contradictory results were generated in the findings. With regard to the study of Lamb (2012), regional differences were first taken into consideration.

\section{Research Questions}

As stated above, the importance of the L2 Motivational Self System has been proved. However, few studies from the Self perspective can be found in China (e.g., Magid, 2009; Liu, 2007). Attempting to contribute to the motivation research under the Chinese context, two research questions were formulated:

Research Question 1:

1.1 Does the Ideal L2 Self correlate to integrativeness?

1.2 Can the Ideal L2 Self better explain the learners' intended learning efforts toward English learning than integrativeness? If yes, to what extent?

The two sub-questions are based on the previous study of Taguchi et al. (2009), aiming to validate whether the Ideal L2 Self can make a greater contribution than integrativeness to English learning among Chinese highschool learners.

Research Question 2:

Does each core component (Ideal L2 Self, Ought-to L2 Self and L2 learning experience) of the L2 Motivational Self System correlate to learners' intended learning effort? If yes, which one is the most correlated factor to the learners' intended learning effort?

My interest in this question came from the study of Kormos and Csizér (2009). This question intended to probe the main factors that explain learners' motivation to learn English among the three components of the L2 Motivational Self System in Chinese educational context.

\section{Research Method}

4.1 Participants

128 high school Grade one students were randomly selected from 4 high schools in Wuhan, a city in central China. The average age of the participants was 15.7. The length of time they devoted to learning English ranged from 6 to 10 years. According to their English teacher, they could be regarded as the intermediate-level English learners as they had passed the high-school English entrance examination. All of them participated in the survey (questionnaire). As the information sheet informed that those who fill in the questionnaire survey could take part in the follow-up interview, six participants then joined the interview. Their Chinese names have been replaced by English names to guarantee their anonymity.

\subsection{Instrument}

A mixed methods approach of questionnaire with follow-up semi-structured interview was utilized in the study.

(1) Questionnaire 
The questionnaire employed in the study consisted of three sections: the first two sections attempt to evaluate learners' attitudes towards English learning and the factors affecting their L2 motivation. Section three is mainly designed to collect participants' background information. Items in first two sections are the six-point Likert-type questions, which were developed on the basis of Dörnyei et al. (2006), Dörnyei and Ushioda (2011) and Taguchi et al. (2009). There are 25 descriptive statement-questions in the first section with the rating scale ranging from "strong disagreement" to "strong agreement". Similarly, section two is a 5-item rating-scale ranging from "not at all" to "very much". The questionnaire (English version) can be seen in Appendix 1.

Before the experiment has been conducted, the pilot study of the questionnaire was carried out. The wording of item content and consistency between two version questionnaires were checked and revised to warrant the good reliability of the questionnaire.

The key components relating to L2 motivation are measured by 30 items:

Intended learning efforts towards English (Evaluation criterion): e.g., I would like to try my best to learn English. (Item 4)

Ideal L2 Self: e.g., I hope one day I can speak fluent English with a native accent. (Item 6)

Ought-to L2 Self: e.g., If I do not get a high score in the English exam, it will harm my future study. (Item 12)

Attitudes towards learning English: e.g., Do you have high expectations for English class in school? (Item 27)

Integrativeness: e.g. How important do you think learning English is to know more about the culture of Englishspeaking countries? (Item 30)

Family influence: e.g., My parents believe that learning English is important for me and put a lot of pressure on me to do so. (Item 25)

(2) Semi-structured interview

The qualitative data were collected by semi-structured interview through the online chatting software WeChat. The questions in the interview were adapted from previous L2 motivation studies, such as Lamb (2009) who employed the interview as a tool for data collection.

\subsection{Procedure and Data Analysis}

Questionnaire

Prior to the study, participants were informed about the purpose and content of the study. After carefully check the details of the questionnaire, only 121 copies were valid. Three participants mistakenly circled two answers in one item. Four participants skipped items, thus resulting in incomplete answers for the survey. It was decided that those invalid questionnaires should be excluded from the data set. Then data collected were analyzed by SPSS.

To ensure the reliability of the subscales, Cronbach Alpha coefficients (internal consistency) for each variable were analyzed by SPSS. For variable of intended learning effort, Ideal L2 Self, Ought-to L2 Self, attitudes towards English learning and integrativeness, one item was deleted to increase the reliability. All items in the scale of family influence were removed as the alpha score was lower than .60 . The reliability coefficients of the final scales are listed in Table 1.

Table 1 Cronbach Alpha Coefficients of the Final Scales

\begin{tabular}{ccc}
\hline & Number of items & Cronbach alpha \\
\hline Intended learning effort & 5 & .892 \\
Ideal L2 Self & 4 & .856 \\
Ought-to L2 Self & 6 & .758 \\
Attitudes towards English learning & 3 & .869 \\
Integrativeness & 2 & .782 \\
\hline
\end{tabular}

To address two research questions from the quantitative perspective, the correlation technique in SPSS was utilized to examine the relationship between the integrativeness and the Ideal L2 Self, between each dimension of the Self system and criterion (intended learning effort).

Interview

To better guarantee authentic qualitative data gathered from the interview, participants should answer all questions independently without the companion or help from parents or teachers. Further, to ease the interview environment, pre-interview greetings followed with background information questions were used to initiate the conversation. Then questions were switched to topics regarding future goals, self-imagination, English learning experience as well as the influence from family members to the language learning. After that, all recorded conversations were transcribed.

The interview data were coded in accordance with the main L2 motivation theories (e.g., Gardner's SocioEducational Model, L2 Motivational Self System). Specifically, integrativeness. learner's intended efforts, plus three key components of the Self system. In order to better interpret the data, each dimension followed by an illustration is presented in the below:

Integrativeness: e.g., Tina: "I want to expose myself to a sufficient authentic English-speaking environment." 
Ideal L2 Self: e.g., Helen: "I hope I will have many foreign friends (from English-speaking countries) in the future."

Ought-to L2 Self: e.g., David: "I should not make stupid mistakes in the English lessons otherwise the teacher will be disappointed with me."

Language learning experience: e.g., Crystal: "I do not like the learning environment in English lessons as the teacher only pays attention to top students...I feel abandoned...."

Intended learning effort: e.g., Zoe: "I will try my best to improve my spoken English."

\section{Findings and Discussion}

5.1 Results of Research Question 1.1

To explore the relationship between the Ideal L2 Self and integrativeness, a correlation analysis was utilized between two constructs, as is shown in Table 2. As the p value is less than .01, the correlation between two variables is remarkably significant (.748). According to Dörnyei (2007), two variables are of equal importance only if the correlation coefficient between the two factors is .60 and above. In this regard, two constructs the Ideal L2 Self and integrativeness can be similar in explaining learners' motivation to learn English.

Table 2: Correlation: the Idea L2 Self and integrativeness

\begin{tabular}{|l|c|c|c|}
\hline & & Ideal L2 Self & Integrativeness \\
\hline Ideal L2 Self & Pearson Correlation & 1 & $.748^{* *}$ \\
& Sig.(2-tailed) & & .000 \\
& $\mathrm{~N}$ & 121 & 121 \\
\hline Integrativeness & Pearson Correlation & $.748^{* *}$ & 1 \\
& Sig.(2-tailed) & .000 & 121 \\
\hline
\end{tabular}

**Correlation is significant at the .01 level (2-tailed)

Results of Research Question 1.2

Both qualitative and quantitative results suggested that integrativeness displayed a stronger influence towards students' intended learning efforts to acquire English.

According to the quantitative data analysis (presented in Table 3), though both integrativeness and the Ideal L2 Self showed positive relationship with the criterion (intended learning effort), integrativeness was found to have a relatively higher correlation with intended learning effort (.782) as compared to the Ideal L2 Self (.624), which fails to support better explanatory power of the Ideal L2 Self towards learners' motivation.

Table 3: Correlation: intended learning effort, the Idea L2 Self and integrativeness

\begin{tabular}{|l|c|c|c|c|}
\hline & & Intended learning effort & Ideal L2 Self & Integrativeness \\
\hline Intended learning effort & Pearson Correlation & 1 & .624 & .782 \\
& Sig.(2-tailed) & & .000 & .000 \\
& $\mathrm{~N}$ & 121 & 121 & 121 \\
\hline Ideal L2 Self & Pearson Correlation & .624 & 1 & $.748^{* *}$ \\
& Sig.(2-tailed) & .000 & 121 & .000 \\
& $\mathrm{~N}$ & 121 & $.748^{* *}$ & 121 \\
\hline Integrativeness & Pearson Correlation & .782 & .000 & 121 \\
& Sig.(2-tailed) & .000 & 121 & 121 \\
\hline
\end{tabular}

$* *$ Correlation is significant at the .01 level (2-tailed)

Qualitative analysis of the interview data suggested that a closer relationship between learners' integrativeness and their motivation to learn English. By contrast, learners' Ideal L2 Self were relatively weak and ambiguous.

Regarding integrativeness, all participants reported positive attitudes toward English, English-speaking countries and relevant traditions and cultures. Helen mentioned: "I want to continue my study in western countries as they think highly of "practices", while in Chinese educational context, we always emphasize obtaining knowledge from textbooks." Zoe demonstrated great interests in Western cultures, such as Halloween and Christmas. She also expressed her strong will to integrate herself into western life. Besides, participants also showed curiosity about people from other countries. David expressed his wish to communicate with more English and would like to know more about their lifestyle. It is interesting to note that all remaining participants mentioned that the United States made a good impression on them. Tina said that she is fascinated by the diversity and freedom of U.S. Crystal believed her great enthusiasm may be ascribed to the Hollywood movies. John explained: "I like American accent and I practicing it all day because I think it symbolizes the passion, courage and freedom of American people."

Concerning the Ideal self, most of them did not have a clear picture of future self-imagination. When asked about their prospects, both Crystal, Zoe and Helen had no idea whether their future study or career may be relevant to English. As for the short-term goal, they all mentioned obtaining a high score in the English exam. 
David seemed to have a clearer Ideal L2 Self as he depicted his imagined overseas life in the future: "I will become more independent when I study abroad. Also, I will make new friends from other countries. The most important thing is that I can communicate them freely with fluent English." Though David had a general picture about the future, his imagination was strongly associated with the will to integrate with native speakers. Hence, it was unclear which variable had a stronger influence towards his learning motivation. Among all participants, Tina was the only one who can be deemed as a good illustration of the Ideal L2 Self. In her interview, she proudly introduced me her Role idol Siyuan Ma, who had won the first prize in the National English Debating Competition. She said: "I hope I can make a public speech in front of audiences in the English competition." Besides, Tina set a clear goal of her future study and job plan as she wanted to apply for Warwick University and to hunt for a job in a foreign company after graduation.

\subsection{Results of Research Question 2}

The research question 2 aimed to investigate the relationship between learners' intended learning effort and the three dimensions of L2 Motivational Self System.

According to the quantitative data analysis (showed in Table 4), correlation coefficients yielded that all three motivational variables (the Ideal L2 Self, the Ought-to L2 Self and language learning experience) of the Self system were significantly correlated with intended learning effort (.606, .333 and .756 respectively), which indicating the English learning experience had the strongest impact on intended learning effort, with the Oughtto L2 Self had the least influence.

Table 4: Correlations: intended learning effort, the Idea L2 Self and integrativeness

\begin{tabular}{|c|c|c|c|c|c|}
\hline & & $\begin{array}{c}\text { Intended learning } \\
\text { effort }\end{array}$ & Ideal L2 Self & $\begin{array}{c}\text { Ought-to L2 } \\
\text { Self }\end{array}$ & $\begin{array}{c}\text { Attitudes to } \\
\text { English learning }\end{array}$ \\
\hline $\begin{array}{l}\text { Intended } \\
\text { learning } \\
\text { effort }\end{array}$ & $\begin{array}{c}\text { Pearson } \\
\text { Correlation } \\
\text { Sig. (2-tailed) } \\
\mathrm{N} \\
\end{array}$ & $\begin{array}{c}1 \\
121\end{array}$ & $\begin{array}{c}.624 * * \\
.000 \\
121 \\
\end{array}$ & $\begin{array}{l}.382 * \\
.009 \\
121 \\
\end{array}$ & $\begin{array}{c}.784 * * \\
.000 \\
121 \\
\end{array}$ \\
\hline Ideal L2 Self & $\begin{array}{c}\text { Pearson } \\
\text { Correlation } \\
\text { Sig. }(2-\text { tailed }) \\
\mathrm{N}\end{array}$ & $\begin{array}{c}.624 * * \\
.000 \\
121 \\
\end{array}$ & $\begin{array}{c}1 \\
121 \\
\end{array}$ & $\begin{array}{l}.265^{*} \\
.028 \\
121\end{array}$ & $\begin{array}{l}.633 \\
.000 \\
121 \\
\end{array}$ \\
\hline $\begin{array}{l}\text { Ought-to L2 } \\
\text { Self }\end{array}$ & $\begin{array}{c}\text { Pearson } \\
\text { Correlation } \\
\text { Sig. }(2-\text { tailed }) \\
\mathrm{N} \\
\end{array}$ & $\begin{array}{l}.382 * \\
.009 \\
121 \\
\end{array}$ & $\begin{array}{l}.265^{*} \\
.028 \\
121 \\
\end{array}$ & 121 & $\begin{array}{l}.208 \\
.058 \\
121 \\
\end{array}$ \\
\hline $\begin{array}{ll}\text { Attitudes to } \\
\text { English } \\
\text { Learning }\end{array}$ & $\begin{array}{c}\text { Pearson } \\
\text { Correlation } \\
\text { Sig. }(2-\text { tailed }) \\
\mathrm{N} \\
\end{array}$ & $\begin{array}{c}.784 * * \\
.000 \\
121 \\
\end{array}$ & $\begin{array}{c}.633 * * \\
.000 \\
121 \\
\end{array}$ & $\begin{array}{l}.208 \\
.508 \\
121 \\
\end{array}$ & 121 \\
\hline
\end{tabular}

**Correlation is significant at the .01 level (2-tailed)

Qualitative analysis of the interview data hinted the English learning experience, be it pleasant or unpleasant, played a great part in shaping the learners' motivation in learning English. It is surprising to notice that most students expressed their negative feelings toward English lessons, especially the teaching methods employed in the class. As David mentioned: "I dislike the English lessons in school as the teacher only focuses on the grammar rather than useful expressions that can be used for real communication". Tina also complained: "In the class, we are facing endless exam papers. It's not interesting at all. Students have no incentive to join the class". Besides the teaching methods in the class, the relationship between teachers and students can be regarded as another factor. Zoe mentioned that her teacher scolded her in front of classmates as she got a low score in the exam. And since then she had little interest to learn English. Similarly, Crystal said that her English teacher only paied attention to top students and she felt demotivated and abandoned in class. Nevertheless, participants also reported pleasant experiences in English learning. According to John, he enjoyed the activities such as a daily report or role-plays held in English class. Helen described her positive experience: "My interest in English was cultivated by my English teacher in high school this year. She praised me every time when I made progress in English".

Regarding the Ought-to L2 Self, findings revealed that its influence was not significant enough to be detected. Specifically, most participants mentioned that their parents had no extra requirement for their English learning. Further, when mentioned making mistakes in English lesson, Crystal, Helen and Tina all agreed that there is no need to worry as one should learn from his mistakes. Differently, though Zoe' parents had high expectation for her English, she did not feel stressful: "For me, I learn English because I find it interesting.... parents' requirements can be the impetus that promotes my English learning". Among all participants, John 
seemed to be the only one who demonstrated a strong Ought-to L2 Self. He did not have a clear goal for English learning and tried every means to meet the requirements of parents. John also mentioned: "... the main motive for me to learn English is to get approval from parents and teachers...".

\section{Discussion}

The current study had two goals: (a) to probe the relationship between the Ideal L2 Self and integrativeness and (b) to investigate the relationship between learners' intended learning effort and the three dimensions of L2 Motivational Self System.

With respect to the first goal (questions 1.1), a high correlation was found between the Ideal L2 Self and integrativeness, which is consistent with the finding of Ryan (2009). Ryan (2009) suggested these two variables may dig out the same domain of L2 motivation. In this regard, findings of the research question 1.1 offered possibility of reinterpreting integrativeness by the Ideal L2 Self. However, Kormos and Csizér (2008) reported an opposite result in Hungary as correlation coefficients between two variables were not significant enough. Since it becomes problematic whether the Ideal L2 Self may display a better explanatory power towards English learning than integrativeness does among Chinese high-school learners, findings in research question 1.2 would be further discussed.

Result of research question 1.2 was out of our expectation given that integrativeness turned out to display a stronger influence towards intended learning effort, which is inconsistent to the findings of Ryan (2009) and fail to support the strength the Ideal L2 Self in explaining learners' motivation.

Therefore, integrativeness as a motivational construct outperform than the Ideal L2 Self in this study. The puzzling result may be explained along two lines. The first line of explanation pertains to the context of the study. As the research was undertaken in Wuhan, a second-tier city in central China, in other words, its economy and social development are around or below the average, high-school students in this study had fewer opportunities to expose themselves to the sufficient and authentic English learning environment. The main sources of English learning were mainly from textbooks or the Internet. As a result, they showed a strong will to communicate with native speakers and would like to integrate with them. Hence, such a strong sense of integrativeness may stimulate them to study harder to acquire English. Besides, the context of such less-developed second-tier city Wuhan seemed to have less advantage fostering learners' Ideal L2 Self in English learning. According to Lamb (2012), language learners in big cities were more likely to be motivated by their imagination of the future. Data coded in interviews suggested that participants did not have a clear picture of their future self with the exception of Tina. She was the only one who possessed the typical Ideal L2 and she had lived and studied in Beijing (the capital city of China) for 11 years. As a result, it is easier for her to develop clear goals for English learning and to build up the Ideal L2 Self.

Another possible explanation for the weaker correlation between the Ideal L2 Self and the criterion can be ascribed to the young age of participants. Kormos and Csizér (2008) discovered the strongest influence of Ideal L2 Self towards English learning among adult learners in contrast to other age group learners. Similarly, the better predictive power of the Ideal L2 Self towards the learning effort was found among the elder learners in the study of Ryan (2009). Hence, the age differences of motivation in these studies may lend support for the result of research question 1.2. The participants in this study might not be old enough to form a stable Ideal L2 Self as the majority of them confessed in the interview that they had no ideas about prospects at the current stage.

The research question 2 aimed to explore the three dimensions of L2 Motivational Self System, of which English learning experience reported the highest correlation to intended learning effort. This result is consistent with the finding of Lamb (2009) in the context of Indonesia. Kormos and Csizér (2008) and Csizér and Kormos (2009) also shared similar findings among secondary school learners. As for the university students, learning experience and the Ideal L2 Self were found of equal importance on learners motivated behavior. However, Magid (2009) hold a different view as the Ideal L2 Self were detected greater contribution to L2 motivation, while learning experience was found to be less effective. By comparing and contrasting the results in these studies, younger learners are likely to be affected by the language learning experience. The participants in this study are around a young age and it is easy for them to be affected by the learning environment and experience. It can be seen from the interviews that, to begin with, students' attitudes towards English teacher displayed a strong impact on their English study as harsh relationship and negative feelings about teachers will demotivate their desire to acquire English; second, positive experiences can be the turning point advance their English learning. Hence, it can be justified that their motivation is greatly correlated to their language learning experience.

Moreover, among the three dimensions of the L2 Motivational Self System, the Ought-to L2 Self showed the weakest correlation to the criterion, which is in line with the results of Magid (2009). The marginal role of the Ought-to L2 Self to English learning can be attributed to the less pressure from parents. In interviews, most participants mentioned that their parents did not set requirements and fully supported their decisions on English learning. Though some of them mentioned their parents' high expectations, students were unlikely to be affected 
by the so-called external pressure. As participants in the study were grade one student, they are too young to handle the pressure from the environment. And this has been mentioned by Taguchi et al. (2009) for they claimed that young age learners age was less capable to deal with the pressure from the environment. Therefore, Ought-to L2 Self was not strong enough to promote high-school learners' efforts to learn English.

To sum up, positive correlations can be found between each variable of the Self system and the intended learning effort, among which the English learning experience reported the strongest correlation to the intended learning effort, followed by the Ideal L2 Self, with Ought-to L2 Self having the least.

\section{Conclusion and Implication}

This paper intended to investigate English learning motivation among high-school learners in Chinese context from the perspective of the L2 Motivational Self System and to further validate the theory under the context of China. First, the study found that the core variable of the Self system the Ideal L2 Self shared similarities with integrativeness in explaining English learning motivation. However, data failed to confirm that the Ideal L2 Self can better account for the L2 motivation than integrativeness does in the Chinese context, which is inconsistent with previous studies and can possibly be explained by the context of the less-developed city and the young age of participants. Second, regarding the three core variables of the L2 Motivational Self System, the study hinted that language learning experience may function the most influential factor that promotes high-school students' English learning motivation. The results partially confirmed the age-related differences in L2 motivation, in that language learning experience is the most influential indicator for high-school language learners, followed by the Ideal L2 Self, with the Ought-to L2 Self produced the weakest correlation.

The study has provided some practical implications for language teaching. Firstly, since the importance of English learning experience in motivating young language learners has been proved, teachers may have a great influence towards students' language learning. It is reasonable that teachers from the less-developed area need to be trained and utilized more motivational strategies and flexible teaching methods in the class. Further, since the relationship between teachers and students played a vital part, positive interaction between learners and teachers are highly encouraged as positive interaction may help develop an atmosphere of openness and frankness in the class, which could have generated a genuine exchange of opinions and information between the two parties. Further, this process equipped the teachers with a comprehensive understanding of their students, which allowed the teachers to make a sound judgment of the students. In that case, students may have more positive attitudes to English learning and thus promoted their L2 motivation. Second, as the effect the Ideal L2 Self displayed towards L2 motivation varies in accordance with age, teachers should guide and foster learners to develop future-self, as well as enhance their Ideal L2 Self. Hence, learners that fully prepared for their future self may be highly motivated to learn English due to their sufficient Ideal L2 Self.

\section{Funding}

The author disclosed receipt of the following financial support for the research, authorship, and/ or publication of this article: This research was supported by the grant of Guangdong University of Foreign Studies PhD Candidate short-term exchange scholar programme awarded to the author.

\section{References}

Crystal, D. (2012). English as a global language. Cambridge University Press.

Dörnyei, Z. (2007). Research methods in applied linguistics: Quantitative, qualitative and mixed methodologies. Oxford: Oxford University Press.

Dörnyei, Z. (2009). The L2 motivational self system. Motivation, language identity and the L2 self, 36(3), 9-11. Dörnyei, Z. (2009b). The psychology of second language acquisition. Oxford: Oxford University Press.

Dörnyei, Z., \& Clément, R. (2001). Motivational characteristics of learning different target languages: Results of a nationwide survey. Motivation and second language acquisition, 23, 399-432.

Dörnyei, Z., Csizér, K. and Németh, N. (2006). Motivation, language attitudes and globalisation: A Hungarian perspective. Clevedon: Multilingual Matters.

Dörnyei, Z., \& Ushioda, E. (2009). Motivation, language identity and the L2 self. Multilingual Matters, 36.

Dörnyei, Z., \& Ushioda, E. (2011). Teaching and researching motivation (2nd ed.). Harlow: Pearson Education.

Dörnyei, Z., \& Ushioda, E. (2013). Teaching and researching: Motivation. Routledge.

Gardner, R. C. (1985). Social Psychology and Second Language Learning: The Role of Attitudes and Motivation. London: Edward Arnold.

Gardner, R. C. (1988). The Socio-Educational Model of Second-Language Learning: Assumptions, Findings, and Issues*. Language learning, 38(1), 101-126.

Gardner, R. C. (2007). Motivation and Second Language Acquisition. Porta Linguarum, 8, 9-20.

Gardner, R. C. (2011). The socio-educational model of second language acquisition. Thèmes Canadiens, 24-27.

Higgins, E. T., Klein, R., \& Strauman, T. (1985). Self-concept discrepancy theory: A psychological model for 
distinguishing among different aspects of depression and anxiety. Social Cognition, 3(1), 51-76.

Kleinginna Jr, P. R., \& Kleinginna, A. M. (1981). A categorized list of emotion definitions, with suggestions for a consensual definition. Motivation and emotion, 5(4), 345-379.

Kormos, J., \& Csizér, K. (2008). Age-related differences in the motivation of learning English as a foreign language: Attitudes, selves, and motivated learning behaviour. Language Learning, 58(2), 327-355.

Kormos, J., \& Csizér, K. (2009). Learning experiences, selves and motivated learning behaviour: A comparative analysis of structural models for Hungarian secondary and university learners of English. In Z. Dörnyei, \& E. Ushioda (Eds.), Motivation, language identity and the L2 self (pp. 120-143). Bristol: Multilingual Matters.

Lamb, M. (2009). Situating the L2 self: Two Indonesian school learners of English. In Z. Dörnyei, \& E. Ushioda (Eds.), Motivation, language identity and the L2 self (pp. 229-247). Bristol: Multilingual Matters.

Lamb, M. (2012). A Self System Perspective on Young Adolescents' Motivation to Learn English in Urban and Rural Settings. Language Learning, 62(4), 997-1023.

Liu, M. (2007). Chinese students' motivation to learn English at the tertiary level. Asian EFL Journal, 9(1), 126146.

Magid, M. (2009). The L2 motivational self system from a Chinese perspective: A mixed methods study. Journal of Applied Linguistics, 6, 69-90.

Markus, H., \& Nurius, P. (1986). Possible selves. American Psychologist, 41(9), 954-969.

Masgoret, A. M., \& Gardner, R. C. (2003). Attitudes, Motivation, and Second Language Learning: A MetaAnalysis of Studies Conducted by Gardner and Associates. Language learning, 53(1), 123-163.

Noel, K. A. (2001). Learning Spanish as a second language: Learners' orientations and perceptions of their teachers' communication style. Language learning, 51(1), 107-144.

Reeve, J. (2014). Understanding motivation and emotion. John Wiley \& Sons.

Ryan, S. (2009). Self and identity in L2 motivation in Japan: The ideal L2 self and Japanese learners of English. In Z. Dörnyei, \& E. Ushioda (Eds.), Motivation, language identity and the L2 self (pp. 120-143). Bristol: Multilingual Matters.

Taguchi, T., Magid, M., \& Papi, M. (2009). The L2 motivational self system among Japanese, Chinese and Iranian learners of English: A comparative study. In Z. Dörnyei, \& E. Ushioda (Eds.), Motivation, language identity and the L2 self (pp. 66-97). Bristol: Multilingual Matters.

Ushioda, E. (1996). Developing a dynamic concept of L2 motivation. 239-245. In: T. Hickey, \& J. Williams (eds.), Language, education and society in a changing world. (pp.239-245). Dublin, Ireland: Multilingual Matters.

Ushioda, E. (2001). Language learning at university: Exploring the role of motivational thinking. Motivation and Second Language Acquisition, 23, 93-125.

Wen, F., \& Wang, L. (2004). Factors affecting second language learning. Language Acquistion and Foreign Language Teaching, (9), 28-32.

Winke, P. M. (2007). The psychology of the language learner: Individual differences in second language acquisition. Studies in Second Language Acquisition, 29(1), 143-144.

Yashima, T., Zenuk-Nishide, L., \& Shimizu, K. (2004). Influence of attitudes and affect on willingness to communicate and L2 communication. Language Learning, 54, 119-152.

Zhou, X., \& Rao, Z. (2007). Motivation, Second Language Acquisition and related problems. Foreign Language studies, (2), 39-44. 


\section{Appendices \\ Appendix 1}

\section{Section A}

\section{Questionnaire: Chinese high-school students' L2 motivation}

In section A, please circle the answer regarding to the statements below. It should note that each number (from 1 to 6) correspondents to different degree you view about the statement.

\begin{tabular}{|c|c|c|c|c|c|}
\hline $\begin{array}{c}\text { Completely } \\
\text { disagree }\end{array}$ & Disagree & $\begin{array}{c}\text { Slightly } \\
\text { disagree }\end{array}$ & $\begin{array}{c}\text { Slightly } \\
\text { agree }\end{array}$ & Agree & $\begin{array}{c}\text { Completely } \\
\text { agree }\end{array}$ \\
\hline 1 & 2 & 3 & 4 & 5 & 6 \\
\hline
\end{tabular}

\begin{tabular}{|c|c|c|c|c|c|c|c|}
\hline 1. & I think that I am trying my best to acquire English. & 1 & 2 & 3 & 4 & 5 & 6 \\
\hline 2. & $\begin{array}{l}\text { My parents hold the belief that all well-educated people have a good command } \\
\text { of English, so I have to study English well. }\end{array}$ & 1 & 2 & 3 & 4 & 5 & 6 \\
\hline 3. & I would spend more time in learning English, rather than other subjects. & 1 & 2 & 3 & 4 & 5 & 6 \\
\hline 4. & I would like to try my best to learn English & 1 & 2 & 3 & 4 & 5 & 6 \\
\hline 5. & $\begin{array}{l}\text { Achieving high English language proficiency will make my parents proud of } \\
\text { me. Hence, I have to strive hard to learn English well. }\end{array}$ & 1 & 2 & 3 & 4 & 5 & 6 \\
\hline 6. & I hope one day I can speak fluent English with a native accent & 1 & 2 & 3 & 4 & 5 & 6 \\
\hline 7. & I learn English because the one who I respect consider it necessary. & 1 & 2 & 3 & 4 & 5 & 6 \\
\hline 8. & $\begin{array}{l}\text { My family members give me a lot of pressure on learning English and they } \\
\text { force me to learn English. }\end{array}$ & 1 & 2 & 3 & 4 & 5 & 6 \\
\hline 9 & I hope that I will make many foreign friends when I study overseas. & 1 & 2 & 3 & 4 & 5 & 6 \\
\hline 10 & I am ready to take more efforts to learn English. & 1 & 2 & 3 & 4 & 5 & 6 \\
\hline 11 & I learn English to get approval from others. & 1 & 2 & 3 & 4 & 5 & 6 \\
\hline 12 & If I do not get a high score in the English exam, it will harm my future study & 1 & 2 & 3 & 4 & 5 & 6 \\
\hline 13 & $\begin{array}{l}\text { If I were a native speaker of English, I could imagine myself made great } \\
\text { achievement in English. }\end{array}$ & 1 & 2 & 3 & 4 & 5 & 6 \\
\hline 14 & I have to learn English well otherwise parents will be disappointed in me. & 1 & 2 & 3 & 4 & 5 & 6 \\
\hline 15 & I want to find a job of great relevance to English in the future. & 1 & 2 & 3 & 4 & 5 & 6 \\
\hline 16 & My parents will be very pleased if I achieve high score in the English exam. & 1 & 2 & 3 & 4 & 5 & 6 \\
\hline 17 & I learn English because my best friend considers it important. & 1 & 2 & 3 & 4 & 5 & 6 \\
\hline 18 & I enjoy the English learning environment in English lessons. & 1 & 2 & 3 & 4 & 5 & 6 \\
\hline 19 & I feel happy when I acquire English. & 1 & 2 & 3 & 4 & 5 & 6 \\
\hline 20 & $\begin{array}{l}\text { Obtaining English is important since a well-educated people is supposed to } \\
\text { speak fluent English to communicate with foreigners. }\end{array}$ & 1 & 2 & 3 & 4 & 5 & 6 \\
\hline 21 & $\begin{array}{l}\text { I would continue to study English if tertiary school offers me courses relating } \\
\text { to English in the future. }\end{array}$ & 1 & 2 & 3 & 4 & 5 & 6 \\
\hline 22 & I think I work harder on English than my schoolmates. & 1 & 2 & 3 & 4 & 5 & 6 \\
\hline 23 & $\begin{array}{l}\text { Learning English is important since one can gain respect from others if he } \\
\text { speaks English well in front of others. }\end{array}$ & 1 & 2 & 3 & 4 & 5 & 6 \\
\hline 24 & $\begin{array}{l}\text { I have to acquire English because my parents/teachers have high expectations } \\
\text { for me and ask me to do so. }\end{array}$ & 1 & 2 & 3 & 4 & 5 & 6 \\
\hline 25 & $\begin{array}{l}\text { My parents believe that learning English is important for me and put a lot of } \\
\text { pressure on me. }\end{array}$ & 1 & 2 & 3 & 4 & 5 & 6 \\
\hline
\end{tabular}

\section{Section B}

In Section B, you will have to circle the answer regarding to the following statements. It should note that each number (from 1 to 6 ) correspondents to different degree you view about the statement.

\begin{tabular}{|l|l|l|l|l|l|}
\hline Not at all & Not too much & Just so-so & A little bit & A lot & Very \\
\hline 1 & 2 & 3 & 4 & 5 & 6 \\
\hline
\end{tabular}

\begin{tabular}{|c|c|c|c|c|c|c|c|}
\hline 26 & How much do you like English? & 1 & 2 & 3 & 4 & 5 & 6 \\
\hline 27 & Do you have high expectations for English class in school? & 1 & 2 & 3 & 4 & 5 & 6 \\
\hline 28 & How much would you like to be someone who speaks native-like fluent English? & 1 & 2 & 3 & 4 & 5 & 6 \\
\hline 29 & Do you think learning English interesting ? & 1 & 2 & 3 & 4 & 5 & 6 \\
\hline 30 & $\begin{array}{l}\text { How important do you think learning English is to know more about the culture } \\
\text { of English-speaking countries? }\end{array}$ & 1 & 2 & 3 & 4 & 5 & 6 \\
\hline
\end{tabular}




\section{Section C}

Please fill in the blank.

Age:

Gender:

Birthplace:

(in detail)

Locations of past education experience: (in detail)

Grade:

The length of English learning Years

Please write down at least one reason your motivation to learn English 